\title{
Effect of Different Photoiniciers of Experimental Adhesive Systems on Adhesive Interface Union Resistance
}

\section{Tiago Norões Gomes ${ }^{1}$, Jefferson David Melo de Matos ${ }^{2}$, John Eversong Lucena de Vasconcelos ${ }^{3}$, Karina Andrea Novaes Olivieri ${ }^{4}$ William Cunha Brandt ${ }^{4}$, Milton Edson Miranda ${ }^{4}$}

\section{Abstract}

Aim: The objective of this study was to investigate the performance of experimental resinous adhesives containing different combinations of photoinitiators systems through the bending test.

Material and Methods: Resinous adhesive formulations were prepared with monomer mixtures consisting of $50 \%$ by mass of bisphenol dimethacrylate glycidyl (BisGMA) and $50 \%$ by mass of triethyleneglycol dimethacrylate (TEGDMA). The photoinitiators were used, camphorquinone (CQ) and bis-alkyl phosphinic oxide (BAPO). The co-initiators were diphenyliodonium hexafluorophosphate (DFI) and the amine (dimethylamino methylmethacrylate - DMAEMA) in the 1:1 proportion by mass. The photopolymerizable initiator systems were dissolved in the organic matrix at $0.5 \%$ by mass concentrations, creating eight groups (G1-CQ, G2- CQ/amine, G3- CQ/DFI, G4- CQ/amine/ DFI, G5- BAPO, G6- BAPO/amine, G7- BAPO/DFl, G8- BAPO/amine/ DFI). Samples with $7.0 \mathrm{~mm}$ in length, $2.0 \mathrm{~mm}$ wide and $1.0 \mathrm{~mm}$ height were prepared $(n=12)$. The curing light used was VALO - Ultradent and the curing time was $20 \mathrm{~s}$. The samples were subjected to evaluation of bending test at three points at a speed of $1 \mathrm{~mm} / \mathrm{min}$ to evaluate the flexural resistance (FR).

Results: The results were submitted to analysis of variance with one criterion $(p<0,001)$ and multiple comparisons were performed using Tukey test. Systems with the photoinitiator BAPO showed higher or
1 Master's Degree in Restorative Dentistry, Department of Dental Prosthetics, Faculdade de Odontologia São Leopoldo Mandic SLMANDIC, Campinas, SP, Brazil.

2 Post Graduate Student - Masters Degree Program, Department of Prosthodontics, Universidade Estadual Paulista Júlio de Mesquita Filho UNESP, São José dos Campos,SP, Brazil.

3 Professor of Oral Implantology, Department of Dentistry, Centro Caririense de Pós-Graduação CECAP, Juazeiro do Norte, CE, Brazil.

4 Professor of Dental Prosthetics, Department of Dentistry, Faculdade de Odontologia São Leopoldo Mandic SLMANDIC, Campinas, SP, Brazil.

\section{Contact information:}

Tiago Norões Gomes.

Address: Rua Sulino Duda, 113, Triangulo, Juazeiro do Norte, CE. CEP 63041-185.

Tel: +55 (88) 3512-1590.

”matosjefferson19@gmail.com 
equivalent bending values that demonstrated by the conventional system containing CQ/amine. Systems with the DFI had higher flexural values in relation to those demonstrated by systems without the DFI to $\mathrm{CQ}$.

Conclusion: The use of systems with alternative photoinitiators and co-initiators allows to obtain superior properties to the conventional system, making these promising systems to act both in isolation as associated with conventional systems.

\section{Keywords}

Photoinitiators, Dental; Dentin; Adhesiveness.

\section{Introduction}

The obtaining of a strong and lasting union between the dental substrates and the restorative materials, has been a great challenge of modern dentistry [1]. The technique of enamel conditioning with phosphoric acid represented a milestone in Adhesive Dentistry [2]. Then came the concept of hybridization that over the years has drastically changed the dental practice, by modifying the generations of adhesive systems [3].

The adhesive systems available in the market are varied, which makes it difficult for the clinician to select the material [4]. One of the difficulties is related to the different clinical steps and care to be taken when using the adhesives that have different types of monomers, solvents, photoinitiators [5]. Its mechanism of action on dental substrates, the composition of the different adhesive systems and their implications for incorrect applications; are essential parameters for the success of the system [6].

There are numerous types of adhesive systems in the dental market. Simply put, they can be divided into conventional and self-etching systems [7]. The conventional ones consist of substances that completely remove the Smear Layer and result in the demineralization of the dentinal substance through the use of acidic conditioning [8]. Among the conventional adhesive systems the odontological market presents examples of two steps (acid + primer and bond) and another three steps (acid + primer + bond) [9].

The self-etching systems can be two steps (primer acid + bond) or single step (primer acid and bond together) [10]. The self-etching adhesives are composed of acid resinous monomers that partially modify and/or remove the smear layer, partially demineralizing the surface of the enamel and dentin [11]. However, adhesive systems are photoactivated; and this photoactivation generally occurs in unfavorable environments, such as humid, in the case of conventional systems, or in acidic environments such as self-etching systems. The photoinitiator most used in the formulation of dental composites is camphorquinone (CQ), it absorbs light at the wavelength between 460 and $480 \mathrm{~nm}$ [12].

Diketone (CQ) is a yellowish solid compound containing in its molecular structure a chromatic grouping, which in large quantities improves its mechanical and biological characteristics; but lead to an undesirable yellowing and thus, affecting the final appearance of the polymerized material, mainly clear and translucent [13]. Despite being an efficient photoinitiator, CQ also has a high carcinogenic potential [14]. 
The objective of the present study was to evaluate the bond strength of the adhesive interface, through microtraction tests, of adhesive systems containing different photoinitiator systems.

\section{Materials and Methods}

\section{Preparation of the Tooth Sample}

In this study, 48 third molars ( $n=8)$, newly extracted, free of caries, cracks or fractures were used. The teeth were kept in chloramine solution $(0.5 \%)$ at $4{ }^{\circ} \mathrm{C}$ for $48 \mathrm{~h}$ for disinfection. Afterwards, they were cleaned using pumice paste and water with Robinson type brushes (Microdont ${ }^{\circledR}$, Socorro, SP, Brazil) and analyzed using a magnifying glass (Carl Zeiss ${ }^{\circledR}$, Jena, Germany), with a $10 x$ magnification to discard specimens that were not intact.

The teeth were included in rectangular glass slides with dimensions of $15 \times 40$ mm (IVM BRASIL, glazing, Mogi das Cruzes, SP, Brazil), fixed with sticky wax (ASFER, Indústria Química Ltda., São Caetanos do Sul, SP, Brazil) in such a way that the occlusal surface was facing the outer and upper surface. (Figure 1).

The crowns of the teeth were sectioned $2 \mathrm{~mm}$ below the cusps in their central region, in the lingual-lingual direction, parallel to their long axis with a double-sided diamond disc. (Meinsinger, Neuss, Germany). After the cut, the residues from the manipulation of the specimens were removed with a sequence of Lixa D'água number 600 and 1200 (3M, Sumaré, Brazil), in Politriz Aropol 2V (Arotec Ind. And Comércio São Paulo/SP/Brazil).

\section{(Figure 2).}

The maintenance of the teeth after these procedures was in physiological serum at a temperature of 36 degrees Celsius in a bacteriological oven ECB 1.3 digital Odontobrás Ind. And Com. Equip. Med. Odont. LTDA (Ribeirão Preto, SP, Brazil).

After the polishing to standardize the smear layer, the dentin disks belonging to each of Groups 1 to 6

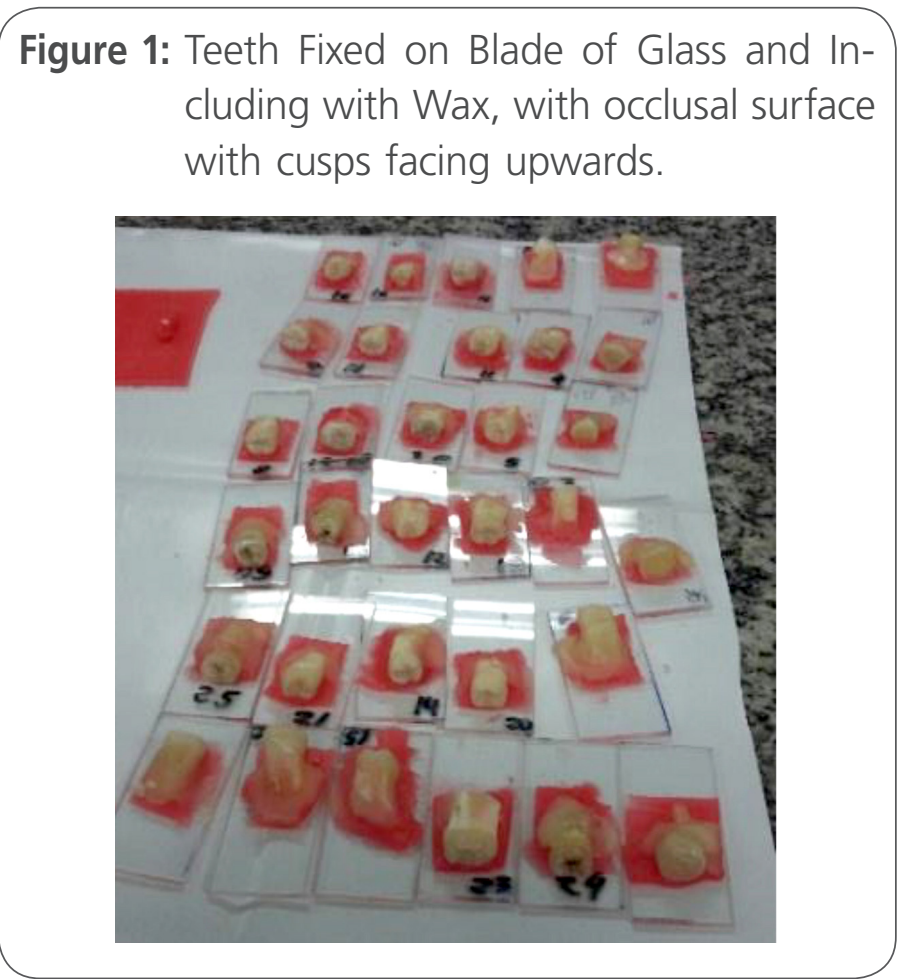

Figure 2: Teeth Cut Off in the Crown Region.

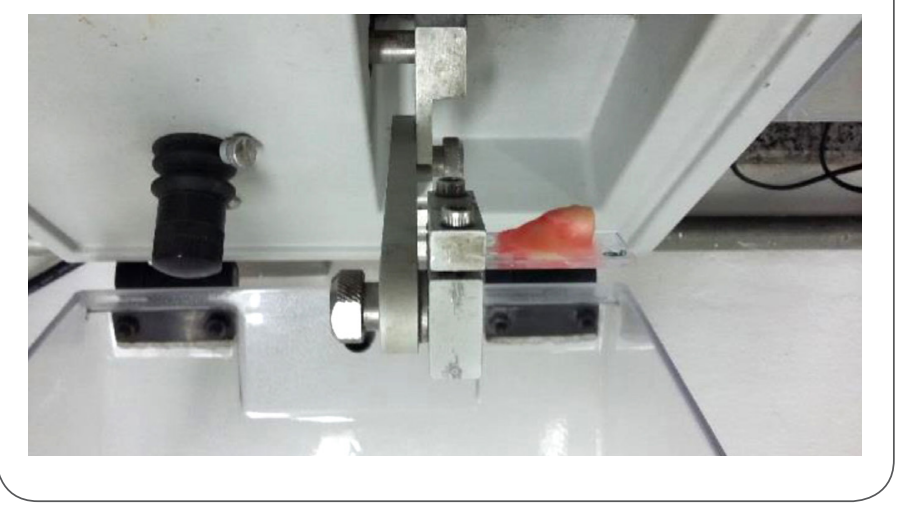

( $n=8$ ) were conditioned with $37 \%$ phosphoric acid (Cond AC $37^{\circledR}$, FGM, Joinville, SC, Brazil) for 15 s and rinsed with copious water for 30s. The excess water was removed with absorbent paper (Figure 3).

Each specimen received the SingleBond adhesive system (3M ESPE, St Paul, USA), which was applied for 10 seconds under constant agitation throughout the dentine surface using a microbrush (KG Sorensen ${ }^{\circledR}$, Barueri, SP, Brazil), followed by a light jet of air for 10s. After the first application a new layer of the adhesive system was applied on the dentin for the same time and agitation condition, followed by a light jet of air also for 10 s and photoactivated 
for 10 s with the Radii ${ }^{\circledR}$ device (SDI, São Paulo, SP, Brazil), with irradiance of $450 \mathrm{~mW} / \mathrm{cm} 2$. (Figure 4).

After application of the adhesive system, restoration of composite resin $\left(Z 250^{\circledR}, 3 \mathrm{M}\right.$ ESPE, St Paul, Minnesota, USA) was done to close the pulp chamber, (Figure 5), using resin increments until all cavity closure, which were photopolymerized for 20s each, with a photopolymerizer used in VALO (Ultradent Products, Inc. - Salt Lake City, Utah, USA) (Figure 6).

Figure 3: Conditioned Teeth.

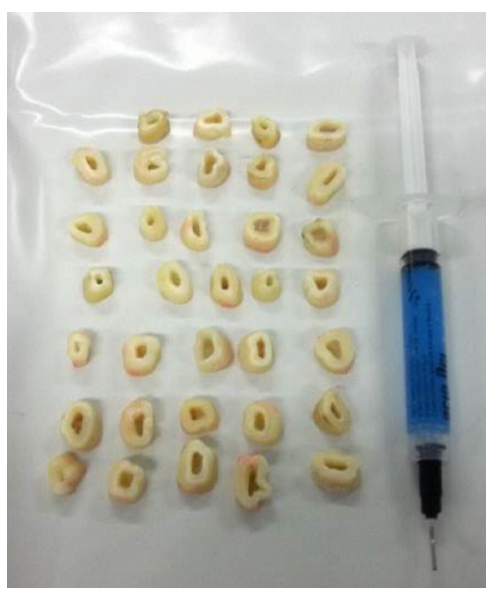

Figure 4: Application of Adhesive System to Close Pulp Chamber.

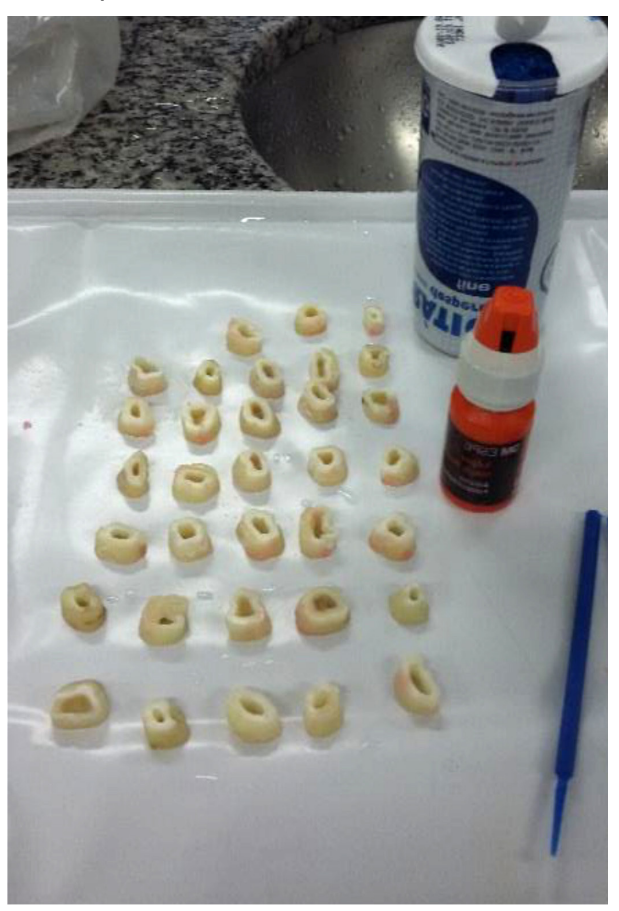

Figure 5: Pulp Cavity Closure with Composite Resin.

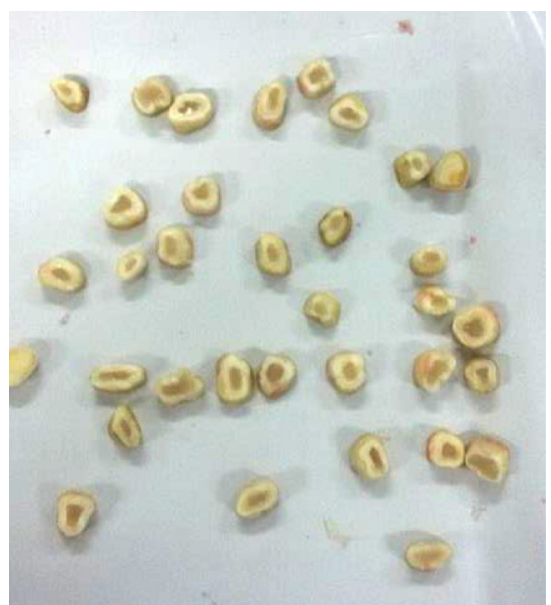

Figure 6: Light Curing Unit VALO-Ultradent.

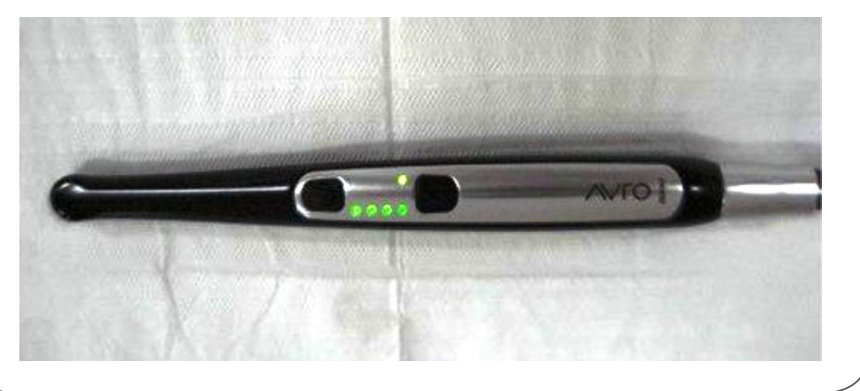

\section{Sample Preparation of Experimental Adhesive Systems}

For this study, the following experimental adhesive formulations were prepared with mixtures of monomers consisting of 50 wt\% BisGMA - Bisphenol Glycidyl Dimethacrylate and 50 wt\% in TEGDMA - Triethylene Glycol Dimethacrylate.

The photoinitiators used were: camphorquinone (CQ) and bis-alkyl phosphinic oxide (BAPO) and co-initiators, diphenyliodonium (DFI) and amine (dimethylamine methylmethacrylate - DMAEMA) in a 1: 1 mass ratio. The photopolymerizable initiator systems were each completely dissolved in the monomer matrix in concentrations of $0.5 \%$ by mass to give the groups:
1. CQ/Amine
2. CQ/Amine/DFI
3. BAPO 


\section{BAPO/Amine}

5. BAPO/DFI

6. BAPO/Amine/DFI (Figure 7).

In addition, the butylated hydroxytoluene inhibitor $(\mathrm{BHT})$ was added to the system in a concentration of $0.1 \%$ by mass to avoid spontaneous polymerization of the monomers. The manipulation of the experimental adhesives was performed in orange filtered light. The formulations of the experimental adhesives used in this study were selected based on the studies of Park et al. (1999), Atai, Watts (2006) and Moin et al. (2001). All reagents were from Sigma-Aldrich Inc., (St. Louis, MO, USA).

Each experimental adhesive containing different photoinitiator systems was applied for 10 seconds under constant agitation on all dentin surfaces with the aid of a microbrush (KG Sorensen ${ }^{\circledR}$, Barueri, SP, Brazil), followed by a light air jet for 10s. After the first application a new layer of the adhesive system was applied on the dentin for the same time and agitation condition, followed by a light jet of air also for 10 s and photoactivated for 10s with the Radii ${ }^{\circledR}$ device (SDI, São Paulo, SP, Brazil), with irradiance of $450 \mathrm{~mW} / \mathrm{cm} 2$.

After application of the adhesive system, a composite resin restoration $\left(Z 250^{\circledR}, 3 \mathrm{M}\right.$ ESPE, St Paul, Minnesota, USA) was made in block form $(4 \mathrm{~mm}$ $\times 4 \mathrm{~mm} \times 8 \mathrm{~mm}$ ) with the aid of addition silicone matrix in the dimensions of each specimen using two resin increments of $2 \mathrm{~mm}$ thickness which will be photopolymerized for $20 \mathrm{~s}$ for each specimen.

\section{(Figures $8 \& 9$ ).}

After $24 \mathrm{~h}$ of restorations, the specimens were cut longitudinally with a double - sided diamond disk (Buehler, model 11 - 4253, 15 LC series, Lake Bluff, ILL 6004, USA) on Isomet 1000 precision metallographic cutter (Buehler, Lake Forest, II, USA) under constant cooling. Each specimen was cut resin - wise in $1 \mathrm{~mm}$ thick sticks in the mesio distal direction perpendicular to the adhesive interface. Subsequently, the specimens were positioned in the vestibulo-lingual direction (rotated $90^{\circ}$ ) and
Figure 7: Experimental Adhesive Systems.

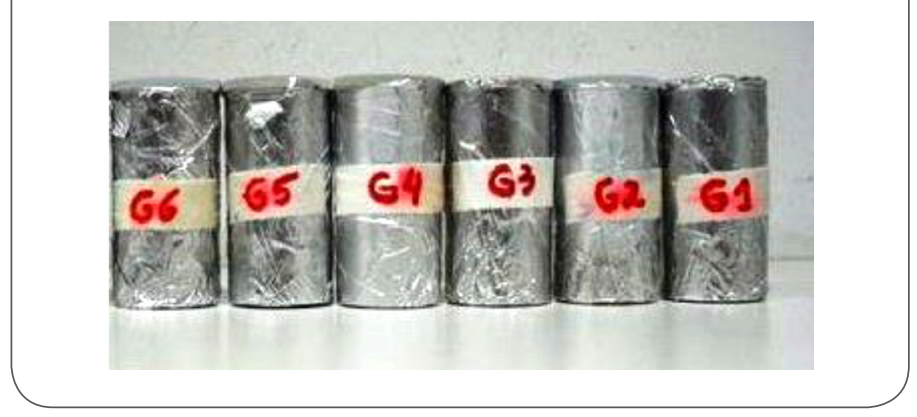

Figure 8: Restored Teeth in Resin and Groups of adhesive systems, digital caliper.

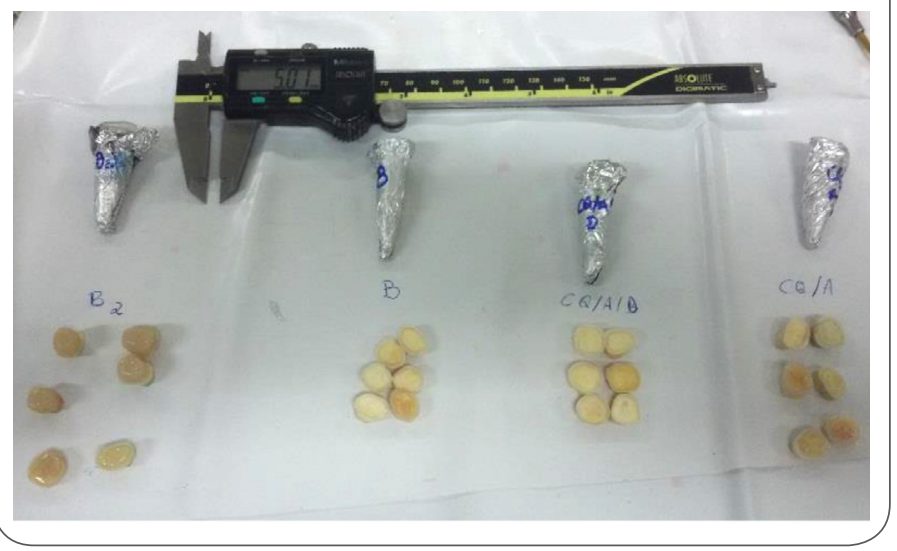

Figure 9: Restored Teeth in Resin.

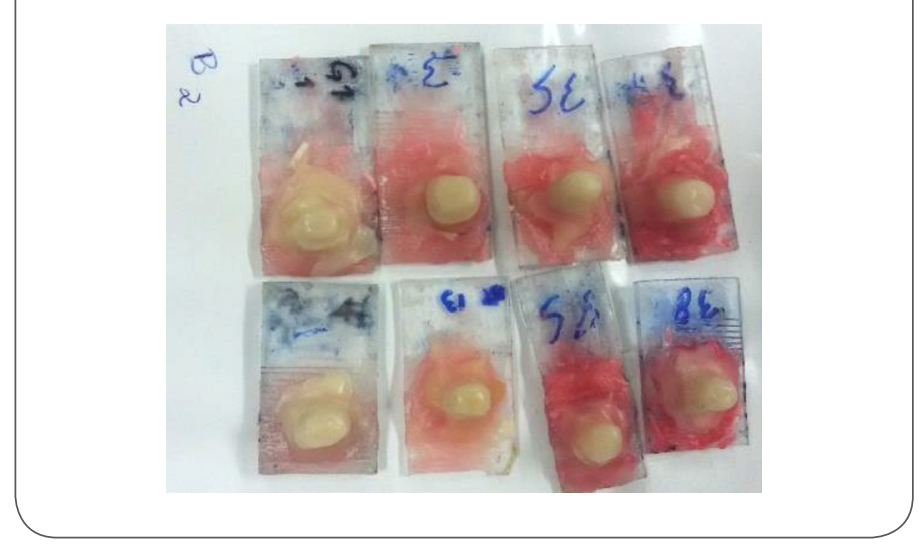

sectioned perpendicular to the adhesive interface giving sticks of $1 \mathrm{~mm}^{2}$. The results of the cuttings were obtained with sticks of dimensions $(4 \mathrm{~mm} \times 8 \mathrm{~m}$ $\mathrm{m} \times 4 \mathrm{~mm})$, composed of a portion of resin $\left(2250^{\circledR}\right.$, 3M ESPE, St Paul, Minnesota, USA) and the other of dentin substrate, and between these 2 structures the adhesive system (bonding interface) (Figure 10). 
Figure 10: Formed Sticks.

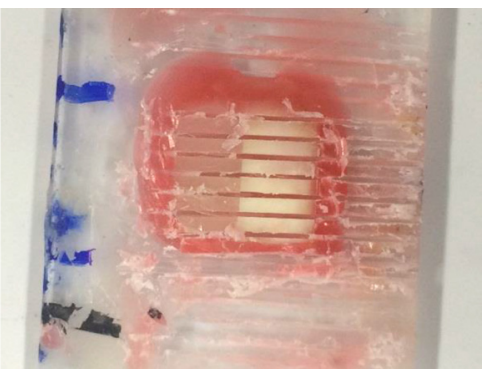

Figure 11: Tooth-Rest Interface and Fixed Sticks.

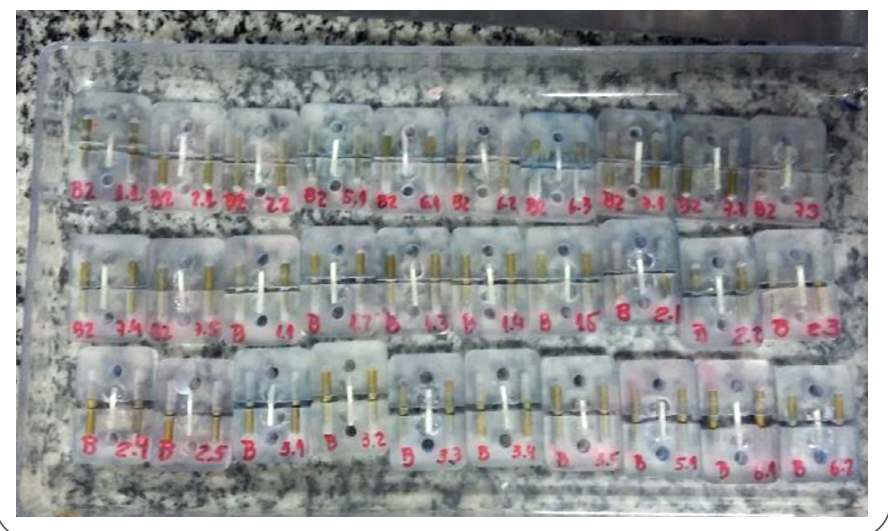

Figure 12: Sticks Ready for Testing with Constant Velocity of $0.5 \mathrm{~mm} / \mathrm{min}$ until toothpick rupture.

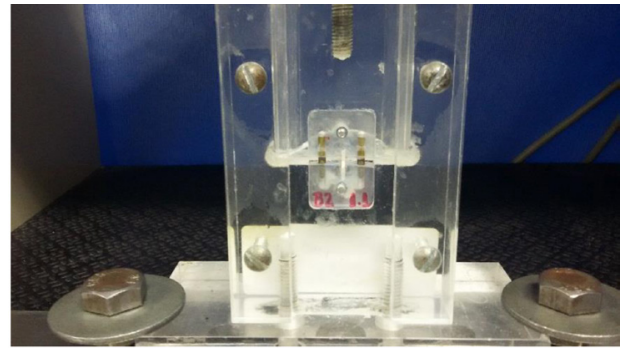

Figure 13: Fractured sticks and ready for Microscope analysis.

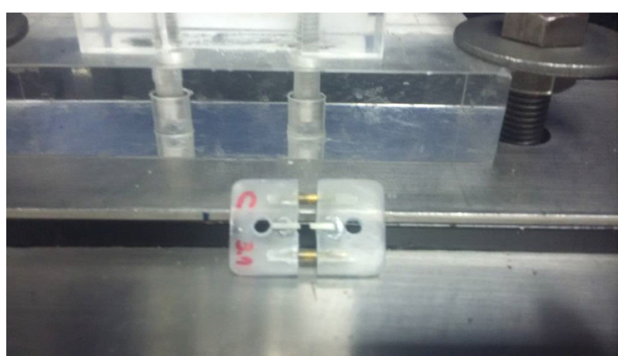

\section{Microtraction Test}

For the evaluation of the bond strength a digital caliper was used to verify the cross-sectional area (height and thickness) of the tooth-restoration interface and the toothpicks were attached to the micro-tensioning device in a Universal Testing Machine (EMIC Ltda., São José (Figure 10), with cyanoacrylate based adhesive (Super Bonder Gel, Loctite, Henkel Ltda., Itapevi, SP, Brazil) at their ends, in order to position the bonding area perpendicular to the long axis of the traction force. The tests were performed at a constant speed of $0.5 \mathrm{~mm} / \mathrm{min}$ until the toothpick rupture. (Figure $11 \& 12$ ).

EK3ST Eikonal Optical and Analytical Equipment (São Paulo, SP, Brazil), the pattern of micro-fractures that correlated with the percentages of fracture types in each experimental group, the obtained values of bond strength. (Figure 13)

The values obtained in Kgf were transformed into MPa using the area of each palito evaluated after being measured with the aid of a digital caliper. The union resistance means were analyzed by statistical method ANOVA 01 (one) factor (factor: union of the adhesive interface) and then by the most appropriate post hoc test.

\section{Statistical analysis}

Prior to the analyzes, union resistance data were assessed for normality by the kolmogorov-smirnov test. They were then subjected to analysis of variance to one criterion. Multiple comparisons were made by the Tukey test. Statistical calculations were performed using the $5 \%(\alpha=0.05)$ level of significance in the SigmaStat 3.5 program (Systat Software Inc., San Jose, California, USA).

\section{Results}

Table 1 shows the mean values and the standard deviation of the bond strength of the different dentin adhesives.

Means followed by distinct letters indicate significant difference between materials. 
Table 1. Mean and standard deviation of union strength values in Mega Pascal (MPa).

\begin{tabular}{|l|c|c|}
\hline \multicolumn{1}{|c|}{ Adhesive } & Union Resistance & MPa \\
\hline BAPO & 32.0 & $13.3 \mathrm{~A}$ \\
\hline BAPO/DFI & 31.0 & $9.7 \mathrm{~A}$ \\
\hline BAPO/Amine/DFI & 25.7 & $9.3 \mathrm{~A}$ \\
\hline BAPO/Amine & 8.6 & $10.4 \mathrm{~B}$ \\
\hline CQ/Amine & 6.0 & $3.1 \mathrm{~B}$ \\
\hline CQ/Amine/DFI & 5.7 & $3.8 \mathrm{~B}$ \\
\hline
\end{tabular}

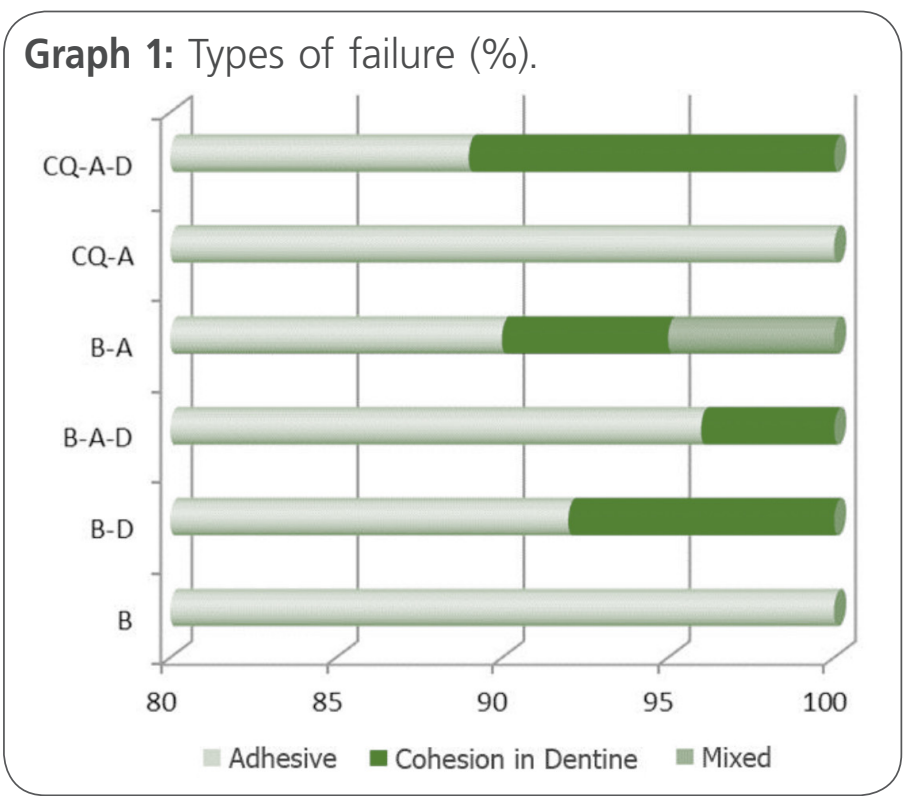

The analysis of variance at one factor showed that there was a statistically significant difference in bond strength values between the different dentin adhesives used $(p<0.01)$.

According to Tukey's test, the adhesives containing the BAPO photoinitiator systems; BAPO/DFI; BAPO/Amina/DFI demonstrated the highest bond strength values, not differing from each other. While the adhesives containing the BAPO/Amine photoinitiator systems; CQ/Amine; CQ/Amine/DFI showed the lowest union strength values similar to each other.

Graph 1 shows the percentage of types of failure that occurred in the different techniques.

The predominant failure pattern for all the evaluated adhesives was adhesive type failure. Since
CQ/Amine/DFI obtained the lowest percentage of adhesive failures (89\%) and adhesives B and CQ/ Amine the largest (100\%).

\section{Discussion}

In search of the success of clinical dental treatments, the quality of the adhesive interface between the composite resins and the dental remnant has been the target of different studies to improve its actiont$\mathrm{fu}$ [15]. Within this theme, the enamel conditioning with phosphoric acid represented a major milestone in adhesive dentistry [16]. Since then, several researchers have been highlighting the use of dedication to the development of new concepts in the area of adhesiveness [17]. In order to continue the discussion on this topic, the purpose of this study was to test different experimental adhesive systems containing different photoinitiator and coinitiator systems, evaluating the bond strength of the adhesive interface to the microtension [18].

Photoinitiators are organic molecules, generally, that can be used alone or as part of a chemical system, which has the capacity to absorb light [1921]. The main characteristics of photoinitiators are photochemistry and photophysics, which trigger the reaction process [22-24]. The requirements fulfilled by these substances are: high molar extinction coefficient in the activation region (application dependent and $\mathrm{FL}$ ); high capacity to generate active species or high quantum yield of free radical formation; solubility in the reaction medium; low chemical degradation before and after the reaction; be odorless; do not cause yellowing of the photocurable resins; be non-toxic and easy to handle [25-30].

The co-initiators are part of a chemical system that does not absorb light but participates in the production of the reactive species [31-33]. The following characteristics were presented: a high oxidation or reduction potential; high reactivity in the addition of the radical to the double bond; does not absorb light at the same wavelength of irradiation 
of the photoinitiator and does not react or interact with the photoinitiator and with the monomers in the ground state [34-37].

The photoinitiator most used in the formulation of dental composites is camphorquinone (CQ) and as belonging to type II, it needs a co-initiator, to finish its polymerization, usually the most used is a tertiary amine [38-40]. One of the commonly used amines is dimethylamine methylmethacrylate (DMAEMA). Another photoinitiator is the bisexual phosphinic oxide derivative (BAPO) [41-43]. It has qualities as good efficiency and does not cause dimming [45]. The BAPO does not need co-initiators in its reaction, because it generates radicals by fragmentation of the molecule after absorption of light in a direct process of photofragmentation, belonging to type I [44-46].

The use of co-initiators, also known as reducing agents, increases the rate or kinetics of the reaction [47]. Therefore, the use of iodonium salt (DFI) could aid the polymerization reaction where there is little availability of light [48]. For this study, therefore, photoinitiators were used: camphorquinone (CQ) and bisexual phosphinic oxide (BAPO); associated or not to different combinations of the co-initiators: iodonium salt (DPI) and amine (DMAEMA) [49-51].

The analysis of variance at one factor showed that there was a statistically significant difference in the bond strength values between the different dentin adhesives used ( $p<0.01$ ) [52-54]. According to Tukey's test, the adhesives containing the BAPO photoinitiator systems; BAPO/DFl; BAPO/Amina/DFI demonstrated the highest bond strength values, not differing from each other [55]. While the adhesives containing the BAPO/Amine photoinitiator systems; CQ/Amine; CQ/Amine/DFI showed the lowest union strength values similar to each other [56].

The results demonstrate that BAPO photoinitiator offers a good combination of the main characteristics of the photoinitiator, as high molar extinction coefficient in the activation region; high capacity to generate free radicals; low chemical degradation before and after the reaction; besides not causing yellowing of the photocurable resins [57]. Although the CQ/amine system has been the gold standard in dental restorations, there are parameters that affect the photopolymerization of this material [58]. The low concentration of this photoinitiator leads to unsatisfactory polymerization results [59].

In addition to camphoronquinone (CQ), it has the ability to absorb blue light and enter a stage of molecular instability; there is also the use of a tertiary amine as a co-initiator [60]. Which is able to accelerate the polymerization reaction by means of an effective exchange of electrons with the CQ [61]. The choice for the tertiary amine occurs because it has some properties such as: a high oxidation potential, does not absorb light at the same wavelength of the photoinitiating substance and does not react with it [62]. Its limitation is that in large quantity can lead to a darkening of the final composite [63].

Due to these several factors, some alternative photoinitiators have been included in the organic matrix of the composites to act alone or synergistically (as co-initiators) with the CQ [64]. Derivatives of aquiline phosphoric oxides (TPO) and

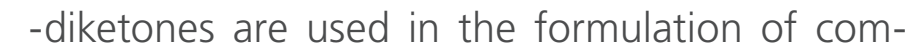
posites to improve polymerization kinetics and decrease the yellowing effect [65]. It is worth noting that another photoinitiator studied is the bisexual phosphinic oxide derivative (BAPO) [66]. As a consequence of their lighter color, these photoinitiators absorb light with wavelength less than camphorquinone (CQ), approximately $400 \mathrm{~nm}$, closer to ultraviolet [67-72]. This photoinitiator showed good efficiency in the formation of four free radicals, and the photoreaction was accompanied by the destruction of the chromophore responsible for the absorption near the ultraviolet, causing the photocleaning of the molecule, which prevents the photoinitiator causes yellowing of the polymer [73-78]. 
The use of co-initiators, also known as reducing agents, increases the rate or kinetics of the reaction [79-82]. Studies have shown that the incorporation of an iodonium salt (DPI) increases the polymerization kinetics through a ternary reaction system (photoinitiator + Amine + Diphenyliodonium Hexa Fluorophosphate - (DPIHFP), without compromising the appearance of the reaction. of iodonium could aid the polymerization reaction where there is little light availability [83-85].

As for the failure pattern, the predominant for all the adhesives evaluated was adhesive type failure. Since CQ/Amine/DFI had the lowest percentage of adhesive failures (89\%) and adhesives B and CQ/ Amine the highest (100\%) [86-88]. Even though CQ/amine initiator system is bound to a high exposure time, and that the use of DFI increases the rate of conversion and polymerization of the compound, the use of DFI associated with the CQ/Amine system was not able to aid in the faults, producing more unfavorable failures [89-91].

\section{Conclusion}

\section{It can be concluded from this study that}

With the exception of the groups containing CQ and CQ/DFI, all others increased the microtensile strength (RM) of the adhesives relative to the CQ/amine group. The systems containing the BAPO photoinitiator presented values of mechanical resistance superior to those demonstrated by the conventional system containing CQ. However, the systems containing the co-initiator AMINA may negatively interfere with the bond strength values. And those that contained the DFI showed values of mechanical resistance superior or equivalent to those demonstrated by the systems without DFI.

\section{Interest Conflicts}

The authors declare that there are no conflicts of interest.

\section{References}

1. Albuquerque PP, Moreira AD, Moraes RR, Cavalcante LM, Schneider LF. Color stability, conversion, water sorption and solubility of dental composites formulated with different photoinitiator systems. J Dent. 2013 Aug:41(3):67-72.

2. Allen NS. Photoinitiators for UV and visible curing of coatings: Mechanisms and properties. Journal of Photochemistry and Photobiology A. Chemistry.1996 Oct; 100:101-107.

3. Andrade MG, Palialol AR, Lancellotti AC, Aguiar $H B$, Watts DC, Gonçalves LS, et al. Effect of diphenyliodonium hexafluorphosphate on resin cements containing different concentrations of ethyl 4-(dimethylamino) benzoate and 2-(dimethylamino) ethyl methacrylate as co-initiators. Dent Mat. 2016 Apr; 32(4):581-9.

4. Anusavice KJ. Phillips materiais dentários. $10^{\mathrm{a}}$ ed. Rio de Janeiro: Guanabara Koogan; 1998

5. Anusavise Kj, Shen C, Rawls RH. Phillips materiais dentários. $12^{\mathrm{a}}$ ed. Rio de Janeiro Elsevier; 2013.

6. Arikawa H, Takahashi H, Kanie T, Ban S. Effect of various light photoinitiators on the polymerization and color of lightactivated resins. Dent Mater J. 2009; 28(4):454-60.

7. Arsu N, Aydin M. The effect of amines on the polymerization of methyl methacrylate. Die angewandte makromelokulare chemie. 1999; 266(1):70-74.

8. Asmusen S, Arenas G, Cook WD, Vallo C. Photobleaching of camphorquinone during polymerization of dimetacrylate-based resins. Dent Mater. 2009; 25:1603-11.

9. Atai $M$, Watts DC. A new kinetic model for the photopolymerization shrinkage-strain of dental composites and resin-monomers. Dent Mater. 2006; 22:785-91.

10. Barghi N, Berry T, Hatton C. Evaluating intensity output of curing lights in private dental offices. J. American Dental Association. 1994; 125(7):992-996.

11. Besse V, Derbanne MA, Pham TN, Cook WD, Le Pluart L. Photopolymerization study and adhesive properties of self-etch adhesives containing bis(acyl)phosphine oxide initiator. Dent Mat. 2016 Apr; 32(4):561-9.

12. Bramra GS, Fleming GJ, Darvell BW. Influence of LED irradiance on flexural properties and vickers hardness of resin-based composite materials. Dent Mater. 2010; 26:148-55.

13. Brandt WC, Schneider LFJ, Frollini E, Correr-Sorinho L, Sinhoreti MA. Effect of different photo-initiatiors and light curing units on degree of conversion of composites. Braz Oral Res. 2010; 24:263-70. 
14. Brandt WC, Silva CG, Frollini E, Souza Junior EJ, Sinhoreti MA. Dynamic mechanical thermal analysis of composite resins with CQ and PPD as photo-initiators photoactivated by QTH and LED units. J Mech Behav Biomed Mater. 2013; 24:21-29.

15. Brandt WC, Tomaselli LO, Correr Sobrinho L, Sinhoreti MA. Can phenylpropanedione influence Knoop hardness, rate of polymerization and bond strength of resin composite restorations? J Dent. 2011; 39(6):438-47.

16. Breschi L, Mazzoni A, Ruggeri A, Cadenaro M, Lenarda R, Stefano DE. Dental adhesion review: aging and stability of the bonded interface. Dent Mater. 2008; 24(1):90-101.

17. Caldarelli PG, Beltrani FC, Pereira SK, Cardoso SA, Hoeppne MG. Light-curing units: evolution and clinical application - a literature review. Odontol. Clín.-Cient. 2011; 10(4) 317-321.

18. Carvalho RM, Carrilho MRO, Pereira LCG, Garcia FCP, Marquezeni Jr.L, silva SMA, et al. Sistemas adesivos: fundamentos para compreensão de sua aplicação e desempenho em clínica. Biodonto 2004: 2(1): 8-86.

19. Carvalho RM. Sistemas adesivos: fundamentos para a compreensão de sua aplicação e desempenho em clínica. Rev Bio Odonto. 2004 Jan-Fev; 2(1):8-74.

20. Christensen T, Morisbak E, Tonnesen HH, Bruzell EM. In vitro photosensitization initiated by camphoquinone and phenyl propanedione in dental polymeric materials. J Photoch Photobio B: Biology. 2010; 100:128-34.

21. Cook WD. Photopolymerization kinetics of dimethacrylates usin the canforquinona/amine initiator system. Polymer. 1992; 33(3):600-9

22. Corrales T, Catalina F, Peinado C, Allen NS. Journal of photochemistry and photobiology A. Chemistry.2003; 159:103.

23. Correa IC. Análise do grau de conversão de uma resina experimental fotopolimerizável: um estudo espectrofotométrico em função de diferentes fotoiniciadores e fontes de luz [tese]. São Paulo: Universidade de São Paulo; 2003.

24. Cramer NB, Stansbury JW, Bowman CN. Recent advances and developments in composite dental restorative materials. J Dent Res. 2011; 90(4):402-16.

25. Decker C, Zahouily K, Decker D, Nguyen T, Viet THI. Performance analysis of acylphosphine oxides in photoinitiated polymerization. Polymer. 2001; 42(18):7551-60.

26. Dewaele M, Asmussen E, Peutzfeldt A, Munksgaard EC, Benetti $A R$, Finné $G$, et al. Influence of curing protocol on selected properties of light-curing polymers: degree of conversion, volumer contraction, elastic modulus and glass transition temperature. Dent Mater. 2009; 25:1576-84.

27. Ely C, Schneider LF, Ogliari FA, Schmitt CC, Correa IC, LimaGS, et al. Polymerization kinetics and reactivity of alternative initiators systems for use in light-activated dental resins. Dent Mater. 2012; 28(12):1199-206.

28. Ferracane JL. Resin composite - state of the art. Dent Mater. $2011 ; 27: 29-38$
29. Fouassier JP. Photoinitiation, photopolymerization and photocuring: Fundamentals and appplications. Munich: Carl Hanser Verlag; 1995.

30. Fusayama T, Nakamura M, Kurosaki N, Iwaku M. Non-pressure adhesion of a new adhesive restorative resin. J Dent Res. 1979; 58(4):1364-70

31. Garcia RN, Souza CRS, Mazucco PEF, Justino, LM, Schein MT, Giannini M. Avaliação da resistência de união de dois sistemas adesivos autocondicionantes - Revisão de literatura e aplicação do ensaio de microcisalhamento. RSBO. 2007; 4 (1):37-44.

32. Gonçalves LS, Moraes RR, Ogliari FA, Boaro L, Braga, RR, Consani S. Improved polymerization efficiency of methacrylatebased cements containing an iodonium salt. Dental Mater.2013; 22-56.

33. Gonçalves,J, Castanho GM, kimpara ET, Uemura ES, Alberto Cara A. Current adhesive systems and perspectives. Revista Odonto • Ano 16, n. 31, jan. jun. 2008, São Bernardo do Campo, SP, Metodista.

34. Harada N, Nakajima M, Pereira NRP, Yagamushi S, Ogata M, Tagami J. Tensile bond stength of a newly developed one-bottle self-etching resin bondig system to various dental substrates. Dentistry in Japan. 2000; 36:47-53.

35. Ikemura K, Endo T. A review of the development of radical photopolymerization initiators used for designing light-curing dental adhesives and resin composites. Dent Mater J. 2010 Oct; 29(5):481-501.

36. Ikemura K, Ichizawa K, Jogetsu Y, Endo T. Synthesis of a novel camphorquinone derivative having acylphosphine oxide group, characterization by UV-Vis espectroscopy and evaluation of photopolimerization performance. Dent Mater J. 2010; 29(2):122-31.

37. Ikemura K, Ichizawa K, Yoshida M, Ito S, Endo T. UV-VIS spectra and photoinitiation behaviors of acylphosphine oxide and bisacylphosphine oxide derivatives in unfilled, light-cured dental resins. Dent Mater J. 2008; 27(6):765-74.

38. Ilie N, Hickel R. Can CQ be completely replaced by alternative initiators in dental adhesives? Dent Mater J. 2008; 27(2):221-8.

39. Ilie N, Hickel R. Resin composite restorative materials. Aust Dent J. 2011; 56(1):59- 66.

40. Jakubiak J, Allonas X, Fouassier JP, Sionkowska A, Andrzejewska E, Linden LA, Rabek JF. Camphorquinone-amines photoinitating systems for the initiation of free radical polymerization. Polymer. 2003; 44:5219-26.

41. Kuniol, Takeshi E. A review of the development of radical photopolymerization initiators used for designing light-curing dental adhesives and resin composites. Dent Mater. 2010; 29:481-501.

42. Kwon TY, Bagheri R, Kim YK, Kim KH, Burrow MF. Cure mechanisms in materials for use in esthetic dentistry. J of Investigative and Clinical Dentistry. 2012; 3:3-16. 
43. Laxe CA, Brum CS, Oliveira SR, Goyatá RF. Self-etching adhesive systems. International J of Dentistry. 2007 Jan-Mar; 6(1):25-29.

44. Leal FB, Lima GS, Collares FM, Samuel SM, Petzhold CL, Piva E, Ogliari FA. Iodonium salt improves the dentin bonding performance in an experimental dental adhesive resin. Int J Adhes Adhesives. 2012; 38:1-4

45. Leprince JG, Hadis M, Shortall AC, Ferrance JL, Devaux J, Leloup $\mathrm{G}$, et al. Photoinitiator type and applicability of exposure reciprocity law in filled and unfilled photoactive resins. Dent Mater. 2011; 27:157-64

46. Loguercio AD, Stanislawczuk R, Mittelstadt FG, Meier MM, Reis A. Effects of diphenyliodonium salt addition on the adhesive and mechanical properties of an experimental adhesive. J Dent. 2013; 41(7):653-658

47. Meerbeek VB, Landuyt VK, Munck J, Hashimoto M, Peumans M, Lambrechts $P$ et al. Technique-sensitivity of contemporary adhesives. Dent Mater. 2005; 24(1):1-13.

48. Meereis CT, Leal FB, Lima GS, Carvalho RV, Piva E, Ogliari FA. BAPO as an alternative photoinitiator for the radical polymerization of dental resins. Dental Mater. 2014 May; 30(9):945-953.

49. Meereis CT, Leal FB, Ogliari FA. Stability of initiation systems in acidic photopolymerizable dental material. Dent Mat. 2016 Apr; 32(4):590-9.

50. Miletic V, Santini A. Micro-raman spectroscopic analysis of the degree of conversion of composite resins containing different initiators cured by polywave or monowave LED units. J Dent. 2012; 40:106-13.

51. Moin Jan $C$, Nomura $Y$, Urabe $H$, Okazaki $M$, Shintani $H$. The relationship between leachability of polymerization initiator and degree of conversion of visible light-cured resin. J Biomed Mater Res. 2001; 58: 42-6.

52. Alvim HH, Alecio AC, Vasconcellos WA, Furlan M, Oliveira JE, Saad JRC. Analysis of camphorquinone in composite resins as a function of shade. Dent Mater. 2007; 23:1245-9

53. Moreno BP, Resistência de união de sistemas adesivos experimentais contendo fotoiniciadores alternativos: estudo in vitro [monografia]. Natal: UFRN; 2015.

54. Moszner N, Salz U, Zimmermann J. Chemical aspects of selfetching enamel - dentin adhesives: A systematic review. Dent Mater. 2005; 21:895-910.

55. Munck J, Van LK, Peumans $M$, Poitevin A, Lambrechts P, Braem $M$ et al. A critical review of the durability of adhesion to tooth tissue: methods and results. J Dent Res. 2005; 84(2):118-32.

56. Nakabayashi N, Pashley, DH. Hibridização dos tecidos dentais duros. São Paulo. Quintessence Editora. 2000; 129.

57. Neumann MG, Miranda JR WG, Schmitt CC, Rueggeberg FA, Correa IC. Molar extinction coefficientes and the photon absorption efficiency of dental photoinitiators and light curing units. J Dent. 2005 July; 33(6):525-32
58. Neumann MG, Schmitt CC, Ferreira GC, Correa IC. The initiating radical yields and the efficiency of polymerization for various dental photoinitiators excited by different light curing units. Dent Mater. 2006 Jun; 22(6):576-84.

59. Nomura $Y$ et al. Thermal analysis of dental resins cured with blue light-emitting diodes (LEDs). J. Biomed. Mat. Res. 2002 Jan; 63(2):209-213

60. Ogliari FA, Ely C, Petzhold CL, Demarco FF, Piva E. Onium salt improves the polymerization kinetics in an experimental dental adhesive resin. J Dent. 2007; 35(7):583-7.

61. Oliveira DC, Rocha MG, Gatti A, Correr AB, Ferracane JL, Sinhoret MA. Effect of different photoinitiators and reducing agents on cure efficiency and color stability of resin-based composites using different LED wavelengths. J Dent. 2015 Dec; 43(12):1565-72.

62. Park SH, Krefci I, Lutz F. Microhardness of resin composites polymerized by plasma arc or conventional visible light curing. Oper. Dent., 2002 Jan/Feb; 27(1):5-30.

63. Park YJ, Chae KH, Ralws HR. Development of a new photoinitiation system for dental light-cure composite resins. Dent Mater. 1999; 15:120-7.

64. Park YJ, Ye Q, Topp EM, Misra A, Kieweg SL, Spencer P. Effect of photoinitiator system and water content on dynamic mechanical properties of a light-cured bisGMA/HEMA dental resin.J Biomed Mater Research. 2009; 1245-51.

65. Parkki A, Pereira PNR, Kalachandra S. Effect of propionaldehyde or 2,3-butanedione additives on the mechanical properties of Bis-GMA analog-based composites. Dent Mater. 2009; 25:2632

66. Pashley DH, Tay FR. Agressiveness of contemporary self-etching adhesives. Part II: etching affects on unground enamel. Dent Mater. 2001 sept; 17(5):430-44.

67. Perdigão J, Gomes G, Lopes M. Influence of conditioning time on enamel adhesion. Quintessence International. 2006; 37(1):35-41.

68. Rabello TB. Estudo comparativo da ação de diferentes filosofias adesivas em esmalte e dentina de dentes humanos permanentes [tese]. Rio de Janeiro: Universidade Federal do Rio de Janeiro; 2003.

69. Reis A, Santos JE, Loguercio A, Bauer JRO. Eighteen-month bracket survival rate: conventional versus self-etch adhesive. The European J of Orthodontics. 2008; 30(1): 94-99.

70. Rueggeberg FA. State-of-the-art: dental photocuring - a review. Dent Mater. 2011; 27; 39-52.

71. Rutsch W, Dietliker K, Leppard D, Misev M, Kolczac U, Rist G. Recent developments in photoinitiatiors. Progress in Organic Coatings. 1996; 27; 227-39.

72. Sakaguchi RL, Musanje L, Ferracane JL. Determination of the optimal photoinitiator concentration in dental composites based on essential material properties. Dent Mater. 2009; 25:9941000 . 
73. Salgado VE, Borba MM, Cavalcante LM, Moraes RR, Schneider LF. Effect of photoinitiator combinations on hardness, depth of cure, and color of model resin composites. J Esthet Restor Dent. 2015 Mar-Apr; 27(1):41-8

74. Salz U, Zimmermann J, SalzerT. Self-curing, self-etching adhesive cement systems. J Adhes Dent. 2005; 7(1):7-17.

75. Sano H, Shono T, Sonoda H, Takatsu T, Ciucchi B, Carvalho R, et al. Relationship between surfasse área for adhesion and tensile bond strength - evalution of a micro-tensile bond test. Dent Mater. 1998; 10(4): 236-40.

76. Schneider LF, Cavalcante LM, Consani S, Ferracane JL. Effect of co-initiator ratio on the polymer properties of experimental resin composites formulated with camphorquinone and phenylpropanedione. Dent Mater. 2009 Mar; 25(3):369-75.

77. Schneider LF, Cavalcante LM, Prahl AS, Pfeifer CS, Ferracane $J$ L. Curing efficiency of dental resin composites formulated with camphorquinone or trimethylbenzoyl-diphenyl-phosphine oxide. Dent Mater. 2012; 28(4); 392-9.

78. Shin DH, Rawls HR. Degree of conversion and color stability of the light curing resin with new photoinitiatior systems. Dent Mater. 2009; 25:1030-8

79. Silva EH, Albuquerque RC, Lanza LD, Vieira GC, Peixoto RT, Alvim $\mathrm{HH}$, Yoshida MI. Influence of different light sources on the conversion of composite resins. Indian J Dent Res. 2011; 22(6):790-794.

80. Silveira FL. Efeito do tipo de fonte de Luz sobre propriedades físicas de cimentos resinosos experimentais contendo diferentes sistemas fotoiniciadores [dissertação].Taubaté: Universidade de Taubaté; 2012.

81. Sodré SC. Materiais autocondicionantes: características gerais e desenvolvimento de sistemas fotoiniciadores alternativos [dissertação]. Rio de Janeiro: Universidade Veiga de Almeida; 2014

82. Stansbury JW. Curing dental resin and composites by photopolymerization. J Esthet Dent. 2000; 12(6):300-8.

83. Tatim LM, Coelho U, Jimenez EEO, Divardim S. Influencia da velocidade de carga nos testes de cisalhamento em colagem de braquetes. Rev Ortho Science. 2010; 3(9):9-15.

84. Timpe HJ, Ulrich S, Decker C, Fouassier JP. Photoinitiated polymerization of acrylates and methacrylates with decahydroacridine-1,8-dione/onium salt initiator systems. Macromolecules. 1993; 26(17):4560-6.

85. Tsai L, Charney E. The triplet state of $\alpha$-dicarbonyls. J Phys Chem. 1969; 73:2462-5.

86. Ultradent Products. VALO LED Curing Light [online]. South Jordan: EUA; 2012 [citado 2015 out 01]. Disponível em: https:// www.ultradent.com/pt-br/Product Instruction Documents/ VALO LED Curing Light - Brazil.pdf

87. Van MB, Munck J, Yoshida Y, Inoue S, Vargas M, Vijay P. Buonocore memorial lecture. Adhesion to enamel and dentin: current status and future challenges. Oper Dent. 2003; 28(3):215-235.
88. Van $M B$, Peumans $M$, Poitevin $A$, Mine $A$, Van EA, Neves $A$ et al. Relationship between bond-strength tests and clinical outcomes. Dent Mater. 2010; 26(2):100-21.

89. Van MB, Yoshihara K, Yoshida Y, Mine A, Munck J, Van LKL. State of the art of self-etch adhesives. Dent Mater. 2011; 27(1):17-28

90. Wang Y, Spencer P, Yao X, Ye Q. Effect of coinitiator and water on the photoreactivity and photopolymerization of HEMA/ camphoquinone-based reactant mixtures. J Biomed Mater Res A. 2006; 78:721-728.

91. Yoshida Y, Nagakane K, Fukuda R, Nakayama Y, Okazaki M, Shintani $\mathrm{H}$ et al. Comparative study on adhesive performance of functional monomers.J Dent Res. 2004; 83:454-8.

92. Turgut $S$, Bagis $B$. Color stability of laminate veneers: an in vitro study. J Dent. 2011; 39:57-64

\section{Publish in International Archives of Medicine}

International Archives of Medicine is an open access journal publishing articles encompassing all aspects of medical science and clinical practice. IAM is considered a megajournal with independent sections on all areas of medicine. IAM is a really international journal with authors and board members from all around the world. The journal is widely indexed and classified Q2 in category Medicine. 